E3S Web of Conferences 1, 10005 (2013)

DOI: $10.1051 / \mathrm{e} 3$ sconf/20130110005

(c) Owned by the authors, published by EDP Sciences, 2013

\title{
Mercury distribution in an abandoned metallurgical plant
}

\author{
R. Millán ${ }^{1}$, M. J. Sierra, T. Schmid, S. Carrasco Gil, D. M. Sánchez Ledesma and F. J. Díaz Puent \\ ${ }^{1}$ CIEMAT- Environmental Department. Avenida Complutense 40, 28040 Madrid, SPAIN, rocio.millan@ciemat.es; \\ mj.sierra@ciemat.es
}

\begin{abstract}
The aim of the work is to evaluate the spatial distribution of $\mathrm{Hg}$ in the soil-plant system within an area where intense activity of $\mathrm{Hg}$ was dominant over a long period. An abandoned metallurgical plant from the $17^{\text {th }}-18^{\text {th }}$ centuries was chosen as the study area. It is situated in Almadenejos within the Almadén mining district (Spain) that constitutes the largest and most unusual concentration of mercury in the world and has provided a third of the entire world production of mercury $(\mathrm{Hg})$. Nowadays, this study area is covered with cinnabar mine tailings and village habitants use it for livestock. The area has elevated $\mathrm{Hg}$ concentrations of natural origin and from human activities. Soil parameters are similar throughout the study area; however, data reveal high variability in total and available $\mathrm{Hg}$ concentrations in soils, making it difficult to establish a tendency. Marrubium vulgare L. has been studied due to its high presence in the field plot, and there is no evidence of phenological toxicity. Furthermore, in spite of elevated $\mathrm{Hg}$ concentrations, a good biological activity is tested in the soil samples. All these characteristics, spatial variation, high $\mathrm{Hg}$ concentration, good biological activity, enhance the peculiarity of the study area for studies involving $\mathrm{Hg}$.
\end{abstract}

Key words: Mercury, soil, Marrubium vulgare L., physical-chemical soil parameters, microbial biomass carbon, soil microbiological activity.

\section{Introduction}

The Almadén area in Central Spain was the mining area with the largest exploitation of $\mathrm{Hg}$, until mining activities ceased at the beginning of this decade. The Almadén $\mathrm{Hg}$ mining district included cinnabar extraction sites (open pits and underground mines), storage areas and metallurgical plants, including mineral furnaces. In two millenniums of activity, this area produced one third of the $\mathrm{Hg}$ used in the human history (Hernández et al. 1999).

The study area for this work is located on the abandoned metallurgical site in Almadenejos. The site dates from the 18th century and is located $12 \mathrm{~km}$ from Almadén. The studied area is approximately $30,000 \mathrm{~m}^{2}$ surrounded by a wall built between 1756 and 1759, and where six pairs of abandoned roasting furnaces are found in ruins. These furnaces were used to obtain primary $\mathrm{Hg}$ from cinnabar.

Higueras et al. (2003) found $\mathrm{Hg}$ concentration in village of Almadenejos that range from 6 to $8889 \mathrm{mg} \mathrm{kg}^{-1}$. For their part, Millán et al. (2006) found values of up to $550 \mathrm{mg} \mathrm{kg}^{-1}$ within the abandoned metallurgical plant. Nowadays, the abandoned site is covered with cinnabar mine tailings and the habitants of the village use it as pasture land for livestock. The dominant vegetation includes Marrubium vulgare among other species (Millán et al., 2006).

The main aim of this study is to evaluate the spatial distribution of $\mathrm{Hg}$ in the soil-plant system within an area where human activity was dominant over a long period. Furthermore, a physico-chemical analysis of soil and study of biological soil parameters were carried out.

\section{Materials and Methods}

Soil and plant samples were obtained in three field campaigns between 2006 and 2008 during the autumn time. After each campaign, laboratory analyses were carried out to determine physical, chemical and biological soil properties as well as total and available $\mathrm{Hg}$ concentrations for both plant and soil samples.

Soil samples were taken from seven points at regular $10 \mathrm{~m}$ spacing. This points were organized in transect that was constituted of three areas: A1, A2 and A3 (Figure 1). At each sampling point, Marrubium vulgare L. plants were also collected.

Plant samples were washed using an ultrasonic bath treatment to remove external contamination and divided into two fractions: the shoot (stem and leaves) and the 


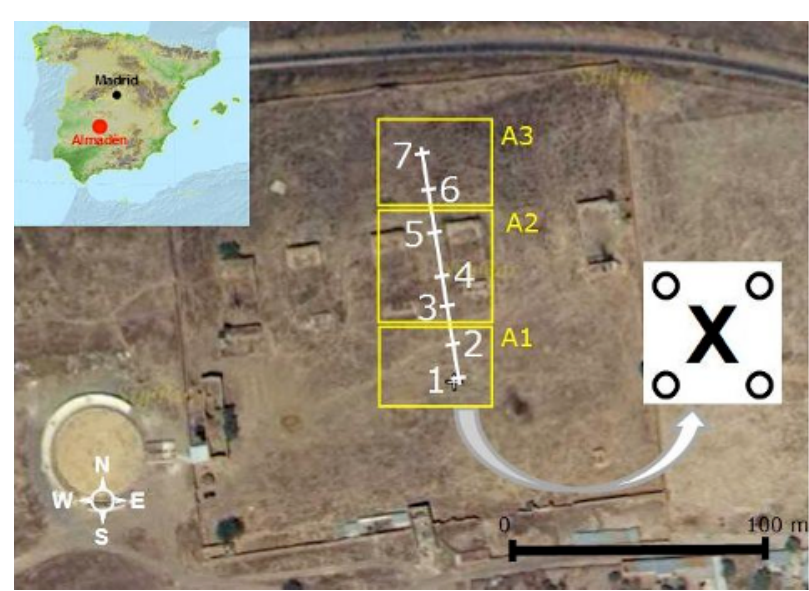

Fig. 1. Experimental field plot and location of the samples areas $(\mathrm{O}=$ soil and $\mathrm{X}=$ soil + plant $)$

root system. Soil and plant samples were dried at room temperature, homogenized and ground. Afterwards, mercury concentration was determined in them using an Advanced Mercury Analyzer (AMA-254).

Microbial analyses were performed with fresh sample after $2 \mathrm{~mm}$ mesh.

Furthermore, a specific six-step sequential extraction procedure developed by Sánchez et al. (2005), was applied to study the distribution of $\mathrm{Hg}$ in soil samples.

\section{Results and Discussion}

Regarding pedological properties of soil, standard soil parameters indicate slight variations along the studied transect. The obtained values for them imply a good condition for pasture land, which is the actual land use at this site.

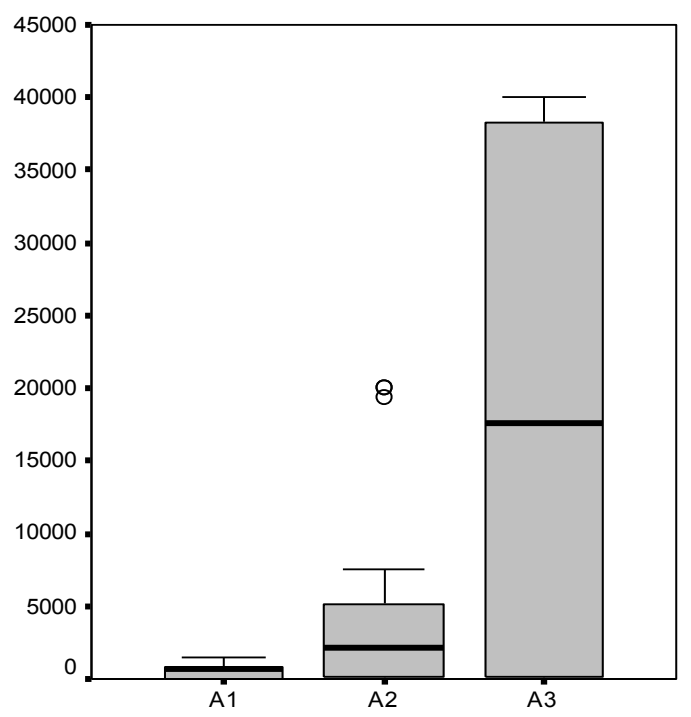

Fig. 2. Total $\mathrm{Hg}$ concentration in soil for the three study areas (A1, A2 and A3)

Figure 2 and 3 show total and available mercury concentration in the three areas (A1, A2 and A3). In all cases, maximum values were obtained in samples collected downslope from the furnaces area (A3) where, cinnabar was stockpiled and, in some cases, slag and waste produced in the roasting processes was deposited. Moreover, the lower part of the transect acts as the reception and accumulation area for the sediments that come from the upper part of the site (A1 and A2).

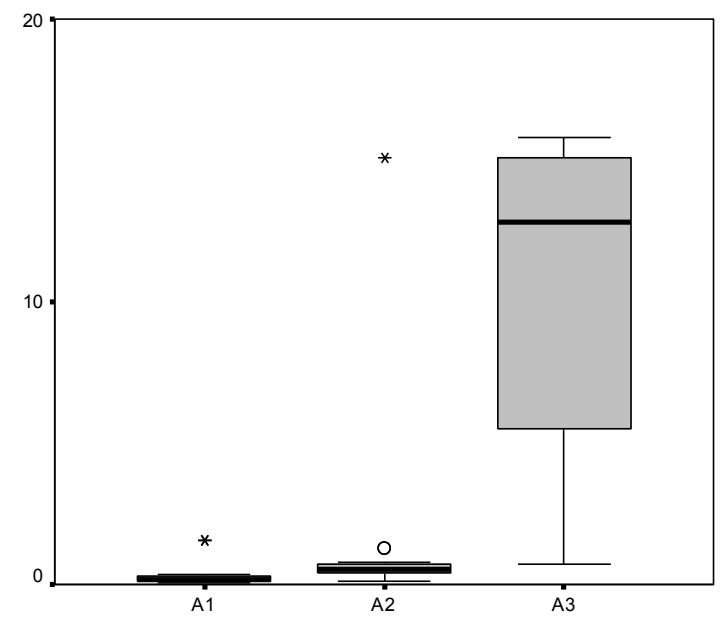

Fig. 3. Available $\mathrm{Hg}$ concentration in soil for the three study areas (A1, A2 and A3).

Regarding the ratio of the percentage of available $\mathrm{Hg}$ concentration in soil with respect to total $\mathrm{Hg}$ concentration in soil, it remains below $3 \%$ in the three areas. It has to be taken into account that in these samples, $\mathrm{Hg}$ is mainly in cinnabar form, which is very stable.

As regards mercury concentration in Marrubium vulgare plant samples, mercury in leaves varied from 6 to $323 \mathrm{mg} \mathrm{kg}{ }^{-1}$, whereas $\mathrm{Hg}$ concentration measured in stems gave lower values, from 1.5 to $77 \mathrm{mg} \mathrm{kg}^{-1}$. Mercury concentration in root varied from 8 to $651 \mathrm{mg}$ $\mathrm{kg}^{-1}$. Our results are within the ranges presented by Millán et al. (2006) and Higueras et al. (2003).

In the three studied areas, $\mathrm{Hg}$ concentration in the stems were similar and in all cases lower than in leaves and roots. The area located upslope from the roasting furnaces (A1), gave similar values in all plant fractions and lower than the other sampling sites. The area along the furnaces (A2), $\mathrm{Hg}$ in plant increased in roots and leaves. In the downslope area (A3), a maximum $\mathrm{Hg}$ concentration was reached and this coincides with the maximum total and available $\mathrm{Hg}$ content in soil.

There is a significant correlation between root $\mathrm{Hg}$ concentration and available $\mathrm{Hg}$ concentration in soil $(\mathrm{r}=0.450, \alpha=0.05)$, but no correlation between root $\mathrm{Hg}$ concentration and total $\mathrm{Hg}$ concentration in soil was observed.

With regard to the distribution of $\mathrm{Hg}$ between the different soil fractions, the results indicate that $\mathrm{Hg}$ distribution among them in the three areas is similar. Mercury is mainly found in the fraction assigned to the final insoluble residues $(31-70 \%)$ that correspond to 
resistant mercury sulphides. The next major amount is released with $6 \mathrm{M} \mathrm{HCl}$, that indicated the $\mathrm{Hg}$ associated to crystalline Fe-Mn oxyhydroxides and/or presented as 6 M HCl-soluble compounds (22-59\%). After, the $\mathrm{Hg}$ associated to oxidizable fraction that can be assigned to the association with organic matter and traces of elemental $\mathrm{Hg}$ is in the range of 5 to $20 \%$. Finally, $\mathrm{Hg}$ associated to water-soluble phases, exchangeable fraction, carbonates and amorphous oxyhydroxides is less than $0.2 \%$.

The experimental area was an historical cinnabar roasting site. The mineral roasting process in the $17^{\text {th }}$ and $18^{\text {th }}$ centuries was incomplete and, accordingly, less efficient than modern systems. This fact justifies the fact that most $\mathrm{Hg}$ was associated to resistant mercury sulphides and to metacinnabar soluble in $6 \mathrm{M} \mathrm{HCl}$ due to the roasting process. Furthermore, a high amount of $\mathrm{Hg}$ was found in the oxidizable fraction that could be associated to high organic matter values and traces of elemental $\mathrm{Hg}$. In the case of the abandoned metallurgy site in Almadenejos, lower cinnabar roasting temperatures were used at the time of activity. This led to lower mercury recovery (Bernaus et al., 2006) and as a consequence higher soil $\mathrm{Hg}$ concentrations are found at the site.

Regarding biological parameters, microbial activity and biomass may indicate the incidence of environmental changes and reveal situations of stress and disruption in soil systems. To avoid the seasonal influence in the magnitude of these parameters, they were analysed for samples obtained in autumn and spring of 2006 and 2007, respectively. This is when the biological activity has reached a maximum in this area. The study of biological parameters took into account several plots within Almadén mining district with different land uses in addition to Almadenejos in order to obtained reference values.

Soil microbial biomass obtained by substrate induced respirometry (SIR) (Anderson and Domsch, 1978) has a value of $919 \pm 341 \mathrm{mg} \mathrm{C}_{\text {mic }} \mathrm{Kg} \operatorname{soil}^{-1}(\mathrm{n}=6)$ while values obtained for the whole area of Almadén $(n=42)$ range from 117.5 to 2104.47 with a mean value of $656.26 \mathrm{mg} \mathrm{C}_{\text {mic }} \mathrm{Kg}$ soil $^{-1}$. Estimating soil microbial biomass by fumigation extraction (FE) (Vance et al. 1987) value obtained in Almadenejos is $989 \pm 278 \mathrm{mg}$ $\mathrm{C}_{\text {mic }} \mathrm{Kg}_{\text {soil }}{ }^{-1}(\mathrm{n}=3)$ the highest obtained in the whole area of Almadén $(\mathrm{n}=15)$ mean $=500 \mathrm{mg} \mathrm{C}_{\text {mic }} \mathrm{Kg} \mathrm{soil}^{-1}$.

High values of metabolic quotient $\left(q \mathrm{CO}_{2}\right)$ should be expected in the Almadenejos furnace, according with the heavy metal concentration in these samples, but values obtained in this plot range $(n=6)$ from 0.64 to 1.43 mgC-CO $\mathrm{CO} \mathrm{C}_{2}{ }_{\text {mic }}{ }^{-1} \mathrm{~h}^{-1}$. Values obtained for Almadén $(\mathrm{n}=42)$ range from 0.57 to $8.11 \mathrm{mgC}^{-\mathrm{CO}_{2}} \mathrm{~g} \mathrm{C}_{\text {mic }}{ }^{-1} \mathrm{~h}^{-1}$ with a median value of $2.58 \mathrm{mgC}-\mathrm{CO}_{2} \mathrm{~g} \mathrm{C}_{\text {mic }}{ }^{-1} \mathrm{~h}^{-1}$. Therefore, the samples from Almadenejos site shown low metabolic quotient values, suggesting that the high mercury concentration is not a disrupting factor in these soils.

Maximum respiratory is proposed as OECD test (Dott, 1995) for assesing if soil contamination has any effect on soil microbial activity. For this estimation is suggested that soils with $\mathrm{CO}_{2}$ production rates under 0.5 $\mathrm{mg} \mathrm{CO}_{2} 100 \mathrm{~g}^{-1} \mathrm{~h}^{-1}$ may be exposed to chemical pollutants. All samples from Almadén $(n=42)$ show maximum respiratory rates from 1 to $16 \mathrm{mg} \mathrm{CO}_{2} 100 \mathrm{~g}^{-1}$ $\mathrm{h}^{-1}$, so the reference value is not of utility for assessing soils from Almadén, but we can compare the maximum respiratory rate of Almadenejos, ranging from 3.51 to $7.11 \mathrm{mg} \mathrm{CO} 2100 \mathrm{~g}^{-1} \mathrm{~h}^{-1}$ with the values obtained for Almadén with a median value of $3.33 \mathrm{mg} \mathrm{CO}_{2} 100 \mathrm{~g}^{-1} \mathrm{~h}^{-1}$. $\mathrm{C}_{\text {mic }}$ to $\mathrm{C}_{\text {org }}$ ratio should show high values in metal polluted soil (Dhalin et al. 2010) due to the loss of soil microbial biomass (Brookes and McGrath, 1984) and the slow rate of soil organic matter mineralization (Baath, 1989). $\mathrm{C}_{\mathrm{mic}} / \mathrm{C}_{\mathrm{org}}$ values obtained from Almadenejos range from $1.39 \%$ to $4.14 \%$ while Almadén values $(n=42)$ range from 0.67 to $5.04 \%$ with a median value of $2.1 \%$, only the lesser value of Almadenejos is under the median value of Almadén.

No one of the analysed soil microbial activity parameters indicate any type of stress/disruption over soil superficial samples of Almadenejos either when comparing when the values obtained for all the analysed soil samples in Almadén or when possible when comparing to external standards, this may be explained by a low microbial availability of mercury and to some extent to physical, chemical and physico-chemical characteristics of the soils in the Almadenejos plot (Millán et al. 2011), with high organic matter content in comparison with the rest of the samples from Almadén and with $\mathrm{pH}$ close to neutrality vs acidic $\mathrm{pH}$ in the rest of the samples.

\section{Conclusion}

Soil parameters are similar in all the samples taken in the study area.

There is correlation between total and available $\mathrm{Hg}$ in soil samples. However, it is important to point out the low percentage of available $\mathrm{Hg}$ despite the significant high amounts of $\mathrm{Hg}$ in soil.

Mercury is mainly found in a form associated to resistant $\mathrm{Hg}$ sulphides and metacinnabar as $6 \mathrm{M}$ $\mathrm{HCl}$-soluble compounds and to organic matter and traces of elemental $\mathrm{Hg}$. The lowest $\mathrm{Hg}$ concentrations were obtained with $\mathrm{Hg}$ associated to water-soluble phases, exchangeable fraction, carbonates and amorphous oxyhydroxides were determined as the lowest concentrations.

Marrubium vulgare could be a good candidate for phytoextraction techniques due to its capacity to accumulate high $\mathrm{Hg}$ content in shoot.

Not one of the analysed soil microbial activity parameters indicate any type of stress or disruption over soil superficial samples of Almadenejos either when comparing the values obtained for all the analysed soil samples in Almadén or when possible comparing to external standards. This may be explained by a low microbial availability of $\mathrm{Hg}$ and to some extent the 
physical and chemical characteristics of the soils in the Almadenejos plot that show optimum values related with critical parameters such as organic matter.

\section{Acknowledgements}

Many thanks go to Minas de Almadén y Arrayanes S.A. (MAYASA), for their effort and support during field surveys. Furthermore, this work is supported by the R\&D Programme of the Spanish Ministry of Science and Innovation.

Authors appreciated the collaboration of the CIEMAT Research Unit on Mass Spectrometry and Geochemical Applications.

\section{References}

Anderson T-H, Domsch KH. Ratios of microbial biomass carbon to total organic carbon in arable soils. Soil Biol. Biochem. 1989; 21: 471-479.

Baath E. Effects of Heavy Metals in Soil on Microbial Processes and Populations (A Review). Water Air Soil Poll. 1989; 47: 335-379.

Bernaus A, Gaona X, Esbrí JM, Higueras P, Falkenberg $G$ and Valiente $M$. Microprobe techniques for speciation analysis and geochemical characterization of mine environments: the mercury district of Almadén in Spain. Environ. Sci. Technol. 2006; 40: 4090-4095.

Brookes PC and McGrath SP. Effects of metal toxicity on the size of the soil microbial biomass. J. Soil Sci. 1984; 35: 341-346.

Dhalin S, Witter E, Martenson A, Turner A and Baath E. Where's the limit? Changes in the microbiological properties of agricultural soils at low levels of metal contamination. Soil Biol. Biochem. 2010; 29:
1405-1415.

Dott W. Dechema Ad-Hoc Committee - Methods for Toxicological/Ecotoxicological Assessment of Soils: Bioassays for Soils: $4^{\text {th }}$ Report of the Interdisciplinary Dechema Committee Environmental Biotechnology - Soil, Frankfurt; 1995.

Hernández A, Jébrak M, Higueras P, Oyarzun R, Morata D, Munhá J. The Almadén mercury mining district, Spain. Mineralium Deposita. 1999; 34: 539-548.

Higueras P, Oryazum R, Biester H, Lillo J, Lorenzo S. A first insight into mercury distribution and speciation in soils from the Almadén mining district, Spain. J. Geochem. Explor. 2003; 80: 95-104.

Millán R, Gamarra R, Schmid T, Sierra MJ, Quejido A, Sánchez DM, Cardona AI, Fernández M, Vera R. Mercury content in vegetation and soils of the Almaden mining area (Spain). Sci. Total Environ. 2006; 368: 79-87.

Millán R, Schmid T, Sierra MJ, Carrasco-Gil S, Villadóniga M, Rico C, Sánchez Ledesma DM and Díaz-Puente FJ. Spatial variation of biological and pedological properties in an area affected by a metallurgical mercury plant: Almadenejos (Spain). Appl. Geochem. 2011; 26: 174-181.

Sánchez DM, Quejido AJ, Fernández M, Hernández C, Schmid T, Millán R, González M, Aldea M, Martín R, Morante R. Mercury and trace element fractionation in Almadén soils by application of different sequential extraction procedures. Analytical and Bioanalytical Chemistry. 2005; 381: 1507-1513.

Vance ED, Brookes PC and Jenkinson DS. An Extraction Method for Measuring Soil Microbial Biomass C. Soil Biol. Biochem. 1987; 19: 703-707. 